\title{
Reações de ativação C-H na preparação de alcalóides pirido[4,3-B]carbazólicos: Síntese total da Elipticina.
}

\section{Bruno K. Serikava*, Joaquim A. M. Castro, Paulo C. M .L. Miranda.}

\section{Resumo}

Foi desenvolvido uma rota para síntese total da elipticina através de uma reação de ciclização intramolecular envolvendo ativação C-H catalisada por paládio. O método envolve a formação de uma isoquinolinodiona a partir de 2,5-dimetoxibenzaldeído seguido de uma reação de adição nucleofílica regiosseletiva da anilina.

\section{Palavras-chave:}

Acoplamento C-H cruzado, Compostos heterocíclicos, Reação de Pomeranz-Fritsch.

\section{Introdução}

Algumas substâncias são capazes de interagir fisicamente com o DNA, distorcendo sua estrutura e função, eventualmente inibindo sua replicação.

Uma destas substâncias é o alcaloide pirido[4,3-b]carbazólico elipticina (1), conhecida por interagir com o DNA através de um mecanismo conhecido como intercalação. ${ }^{[1]}$ A intercalação destes compostos pode ser sucedida pela clivagem do DNA,$^{[2]}$ sendo portanto útil para o tratamento de cânceres, doenças onde há uma anomalia na multiplicação de células.

O objetivo deste projeto é a síntese total da elipticina através da ativação $\mathrm{C}-\mathrm{H}$ catalisada por paládio de uma isoquinolinodiona empregando materiais de partida e reagentes relativamente acessíveis.<smiles>Cc1c2ccncc2c(C)c2c1[nH]c1ccccc12</smiles>

(1)

Figura 1. Estrutura do alcaloide elipticina (1).

\section{Resultados e Discussão}

A síntese proposta parte do 2,5-dimetoxibenzaldeído (2) e, através da reação de Pomeranz-Fritsch via modificação de Bobbit e Jackson, forma a 5,8dimetoxisoquinolina (3), reação cujas condições já foram otimizadas pelo grupo. ${ }^{[3]}$

Em trabalhos anteriores publicados pelo grupo, foi possível a síntese da isoelipticina através da adição nucleofílica de anilinas na posição 7 de 5,8-isoquinolinodionas, dada a regiosseletividade da reação em função do padrão de substituição do intermediário sintético empregado. ${ }^{[4]}$

O foco dos estudos deste projeto é, portanto, a inversão da regioseletividade na adição da anilina: da posição 7 da isoquinolina para a sua posição 6 . As reações posteriores para formação da elipticina (ativação $\mathrm{C}-\mathrm{H}$ na posição 7 , ciclização intramolecular e redução dos grupos metoxi ou oxo) seriam idênticas àquelas utilizadas para formação da isoelipticina. ${ }^{[4]}$
O método desenvolvido neste projeto envolveu a oxidação do nitrogênio piridínico ao seu $N$-óxido (7) seguido da desmetilação dos grupos metóxi nas posições 5 e 8, invertendo a distribuição eletrônica do sistema e favorecendo o ataque nucleofílico de aminas na posição desejada. Obtiveram-se proporções de até 6:1 do produto $\mathrm{N}$-fenilado (5) desejado em relação a seu isômero na reação de adição nucleofílica.

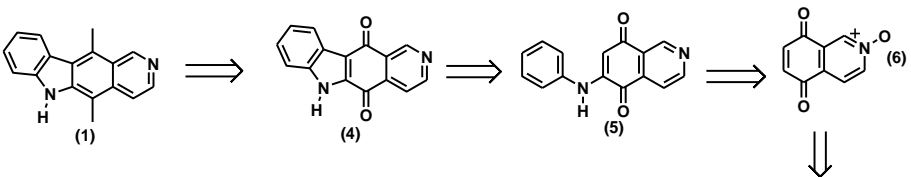

$$
\begin{aligned}
& \underbrace{(2)}_{0}
\end{aligned}
$$

Figura 2. Estratégia sintética utilizada para obtenção da elipticina.

\section{Conclusões}

Através dos estudos realizados foi possível o avanço no estudo da síntese total da elipticina, obtendo-se isoquinolinodionas $\mathrm{N}$-feniladas na posição $6 \mathrm{com}$ alta regiosseletividade.

\section{Agradecimentos}

Ao PIBIC/CNPq, pela bolsa concedida.

1 Nelson, E. M.; Tewey, K. M. e Liu, L. F. Proc. Natl. Acad. Sci. USA. 1984, $\underline{81}$ 1361.

2 Waring, M. J. Annu. Rev. Biochem. 1981, 50, 159-192.

3 Naciuk, F. F. 5,8-Dimetoxisoquinolina como intermediário sintético versátil: Síntese total das Caulibugulonas A, B, C e D e da Isoelipticina. 2014. 254f. Tese (Doutorado em Ciências na área de Química Orgânica) - Universidade Estadual de Campinas, Instituto de Química. Campinas.

4. Naciuk, F. F.; Castro, J. A. M.; Serikava, B. K.; Miranda, P. C. M. L. Straightforward Synthesis of Isoellipticine by Palladium-Catalyzed Coupling Reactions. Chemistry Select, 2018, $\underline{3}, 436-439$. 